\section{Dubai Before Dubai: The Pietiläs and the City Coastline}

\author{
RUBEN GARCIA RUBIO
}

Al Ghurair University

This paper will attempt to highlight the land reclamation as an instrument of urban planning. To achieve this goal, Dubai will be considered as a case study and, specially, Reima and Raili Pietilä's proposal for the Deira Sea Corniche Competition as a visionary proposal which anticipated the creation of artificial islands in the city. Describing the history of the Dubai's coastline and analyzing the Pietiläs' project for its innovative and -at the same time- contextual ideas, the paper will not only offer a new way to approach urban design in Dubai but also to consider the value of land reclamation as a tool for urban development -with its strengths and weaknesses- in order to avoid land consumption and to allow the preservation of most part of the coastline.

In the current global imaginary, Dubai is a charming and futuristic international capital projected to the future. Only 50 years ago, nevertheless, the city was just a small fishing village settled around trading and pearl diving. The discovery and commercialization of oil in the 60 s was a turning point in the history of the Emirate: suddenly, a large number of concrete and curtain-wall high-rise buildings started to arise from the sand of the desert, untill transforming that $2 \mathrm{~km} 2$ small village (1950) into a $150 \mathrm{~km} 2$ global city (2005). ${ }^{1}$

The extension of Dubai's boundaries has not only happened in a specific direction but has widespread in any direction. The city has reached the limit with the Emirate of Sharjah on the North and with the one of Abu Dhabi on the South, has also conquered a large part of the desert on the East and expanded its domain towards the sky with the tallest building in the world, the Burj Khalifa (designed by SOM, 2004-10). The only remaining side to further expand was the coastline on the West side, and the city has also reshaped it. Up to the point of to turn the manmade islands into a distinguishing mark of Dubai, as nowadays the islands of Burj Al Arab (built on an artifical island), Palm Jumeirah or the World (both developed by Nakheel) are among the most world wellknown hotspots to visit.

It is true that Dubai is not the only interesting place to study the phenomenon of land reclamation, in reality there are other cities with older reclamation initiatives. ${ }^{2}$ Yet the case of Dubai is more interesting due to huge media attention and the dimension of the envisioned reclamation, because the expansionist desire of the city attempted to reshape the coastline of the Emirate from its natural $67 \mathrm{~km}$ to a design a new one of $1500 \mathrm{~km}^{3}$
TIZIANO AGLIERI RINELLA

American University of the Emirates (UAE)

\section{INTRODUCTION}

The relation between Dubai and the water is as old as the own existence of the city. The ten-kilometer Creek was the main reason for a community focus on water-need economic activities, as fishing, trading and pearl diving, to settle in that specific place. Those activities became the real engine of Dubai from its origins, and the Creek the real core the city, so the coastline became its most important space.

Among the first accomplishments of Sheikh Rashid II bin Saeed Al Maktoum, when he became Ruler of the Emirate in 1958, was to improve the coastline of the city to transform the small cluster of settlements into a modern port city. ${ }^{4}$ One the one hand, the Creek, the old natural harbor, was widened and dredged to enable larger vessels and coastal steamers to dock on it (1961). On the other hand, two new modern ports were built, Port Rashid (1972) adjacent to the Creek and Jebel Ali Port (1979) near to the border with Abu Dhabi. These large infrastructures not only started the expansion of the city but also an endless relation with its coastline, and they also show how land reclamation is not a new urban tool for Dubai.

Then, the discovery of oil in 1966, and its commercialization three years later, accelerated the transformation of the city. Yet Dubai's oil resources are limited, so the Emirate started to diversify its economy using oil revenues and attracting foreign investments. Hence the Emirate encouraged new economy sectors as tourism, real state, finance or transportation, and all of them are behind the continuity of the reshaping of the coastline of the city. The new wave of coastal projects resumed with the Burj Al Arab Hotel, placed on an artificial island, and Palm Jumeirah in the late 90 s. Since that moment, the coastline of the Emirate has been continuously reshaped until nowadays with many projects as The World, Palm Jebel Ali, Deira Islands... ${ }^{5}$

Nevertheless, there is one proposal that should be highlighted among all projects designed or built to reshape Dubai's coastline, Reima and Raili Pietilä's proposal for the Deira Sea Corniche Competition (1974), due to its innovative and, at the same time, contextual approach.

\section{MASTER DEVELOPMENT PLAN FOR DEIRA SEA CORNICHE COMPETITION}

In July 1974, the Dubai Municipality invited a selected group of international architects to compete as consultants in the competition concerning a Master Plan Development for 

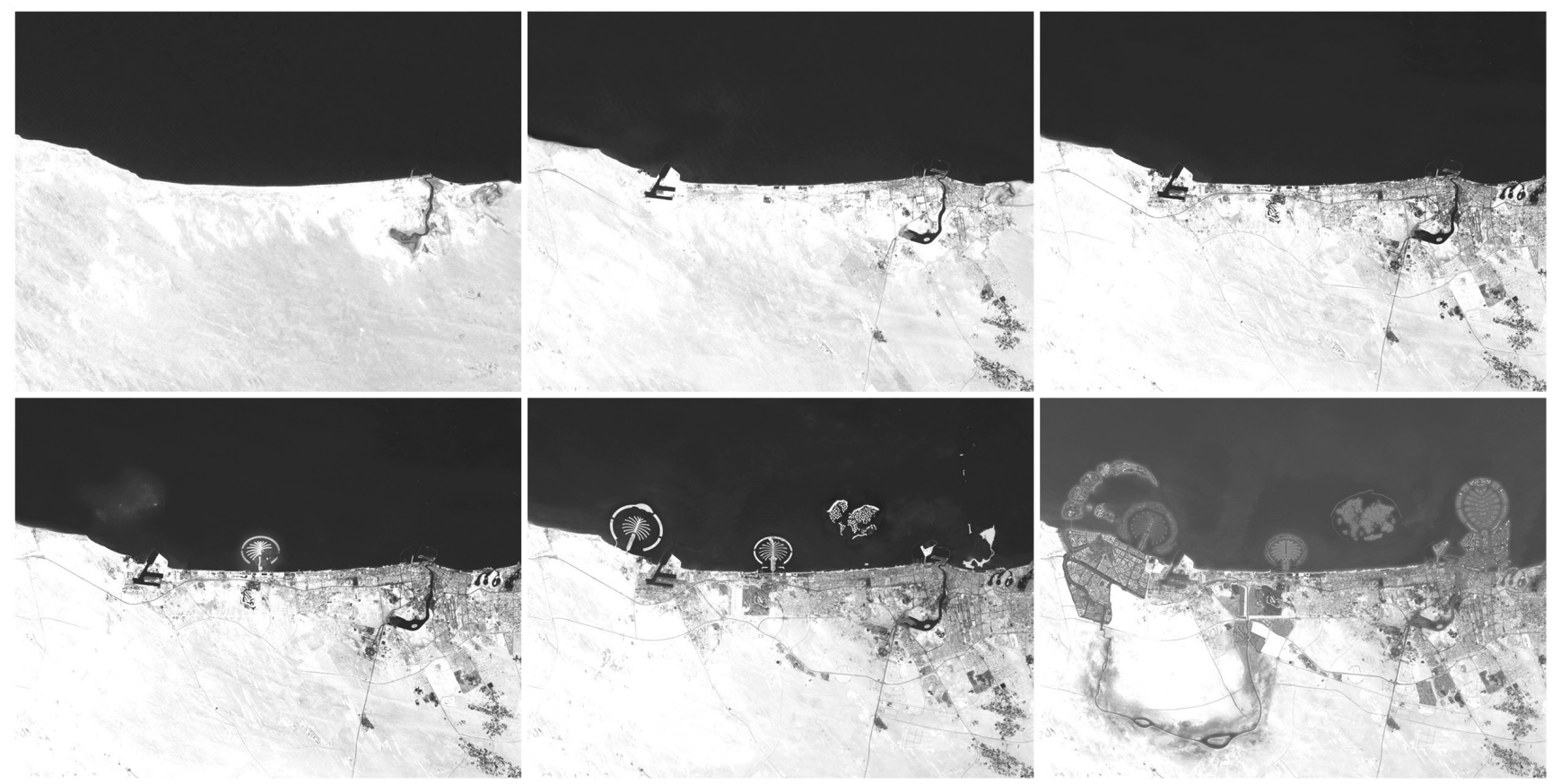

Figure 1: Sequence of Dubai's urban growth: 1970, 1990, 2000, 2005, 2008 and envisioned, NASA and Nakheel

the Deira Sea Corniche, and Reima and Raili Pietilä were among them. ${ }^{6}$

The program outlined by the Municipality did not concern only the design of the Corniche (Seafront) corridor but considered a complete re-assessment of the whole urban agglomeration. ${ }^{7}$

According to the municipality, the primary goal the architects had to face with their proposals for the waterfront were first the enhancement of quality of urban life, creating "visual" and "mental" recreation for the inhabitants, creating an "environment of functional beauty" along an attractive coastal drive. ${ }^{8}$

The spirit of the competition reflected the state of pride and euphoria of the young Arab country, which following the discovery of oil in 1966 was experiencing a sudden unexpected wealth, bringing the Emirati to the international fore. In fact, the competition documents expressed the desire to "give the city the image of a capital."

\section{REIMA AND RAILI PIETILÄ'S PROPOSAL}

The main idea of the Pietiläs' proposal was to protect the city waterfront with a chain of connected islands, which included housing, commercial, educational, cultural or sportive areas, separated from the original coastline by a longitudinal lagoon. This new offshore-city would have also interpreted the traditional Arab city in density, orientation, scale, etc., with a sustainable approach to design able to deal with the local climate issues.
The Pietiläs claimed that all coastal harbour cities in the region had a common model. Therefore, in his attempt to define a semantic expression for the architecture of the new Arab capital he looked at the city of Makalla in Yemen, on the other side of the Indian Ocean, as a model for Dubai's future growth. ${ }^{10}$

Since the beginning of the design process, they started to think about a reassessment of Dubai's urban structure around three main cores, the three "sister cities" of Bur Dubai, Deira and the new development of Khan Creek (at the end of the Creek). This solution pursued a decentralization of the congested whole allowing at the same time a centralization in the three different communities, conceived as "walled cities," organized around architectural landmarks with high-rise building standing along the borders as to "wrap" the lower buildings in the middle.

This arrangement created two opposite space conditions: the feeling to be "inside" the community (inside the core space wrapped by high -rise buildings) or "outside," with wide-open views towards the desert or the sea.

A series of sketches show Pietiläs' design process. The evolution of the corniche's design is particularly interesting. After his in-depth investigation of the city's cultural values, he started with a general zoning of the coastline, defining functions and densities along the carriage way following the tunnel under the creek. Since the beginning, the waterfront was intended to host public and recreational activities. 


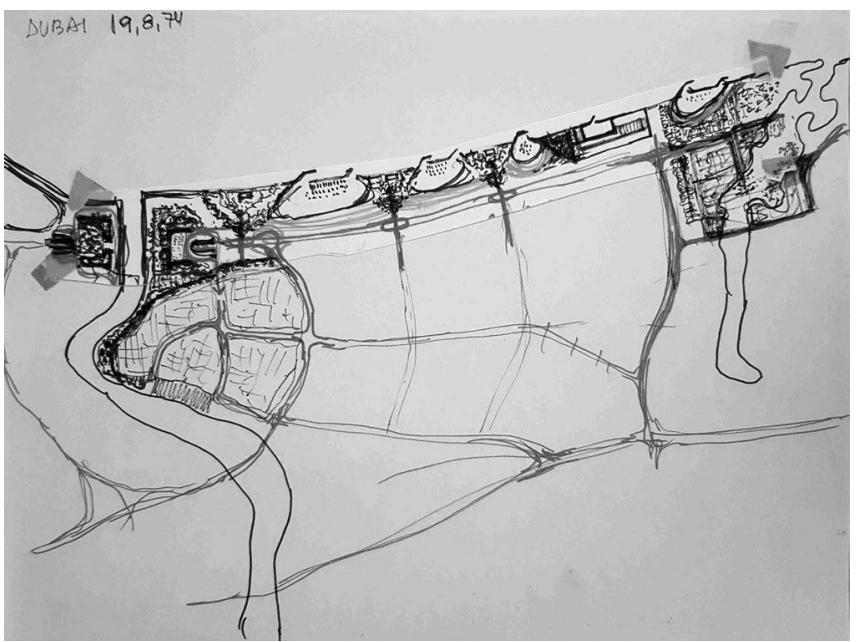

Figure 2: Sketch dated on “19.8.74," 1974, Reima and Raili Pietilä's Archive, The Museum of Finnish Architecture.

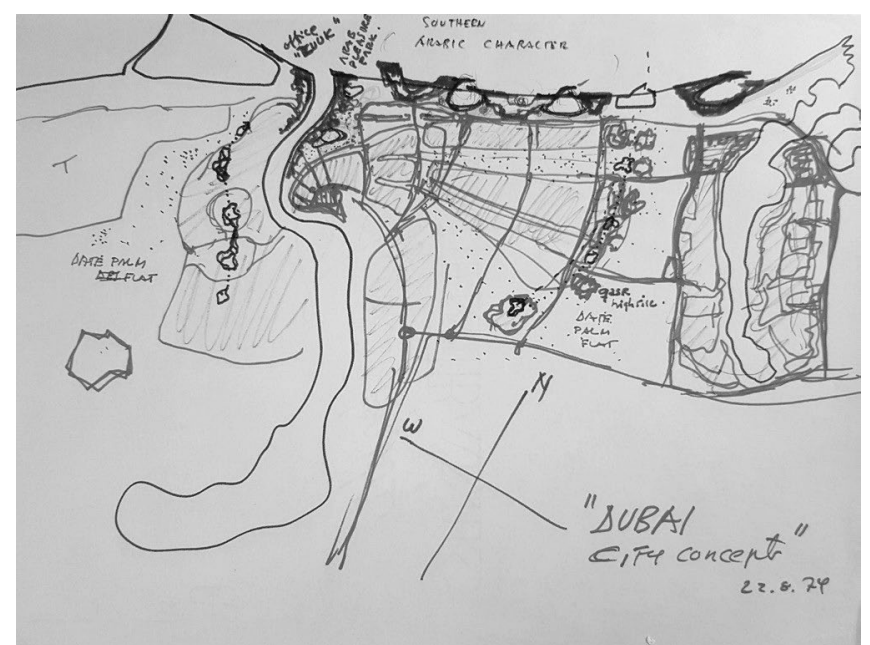

Figure 3: Sketch dated on “22.8.74," 1974, Reima and Raili Pietilä's Archive, The Museum of Finnish Architecture.

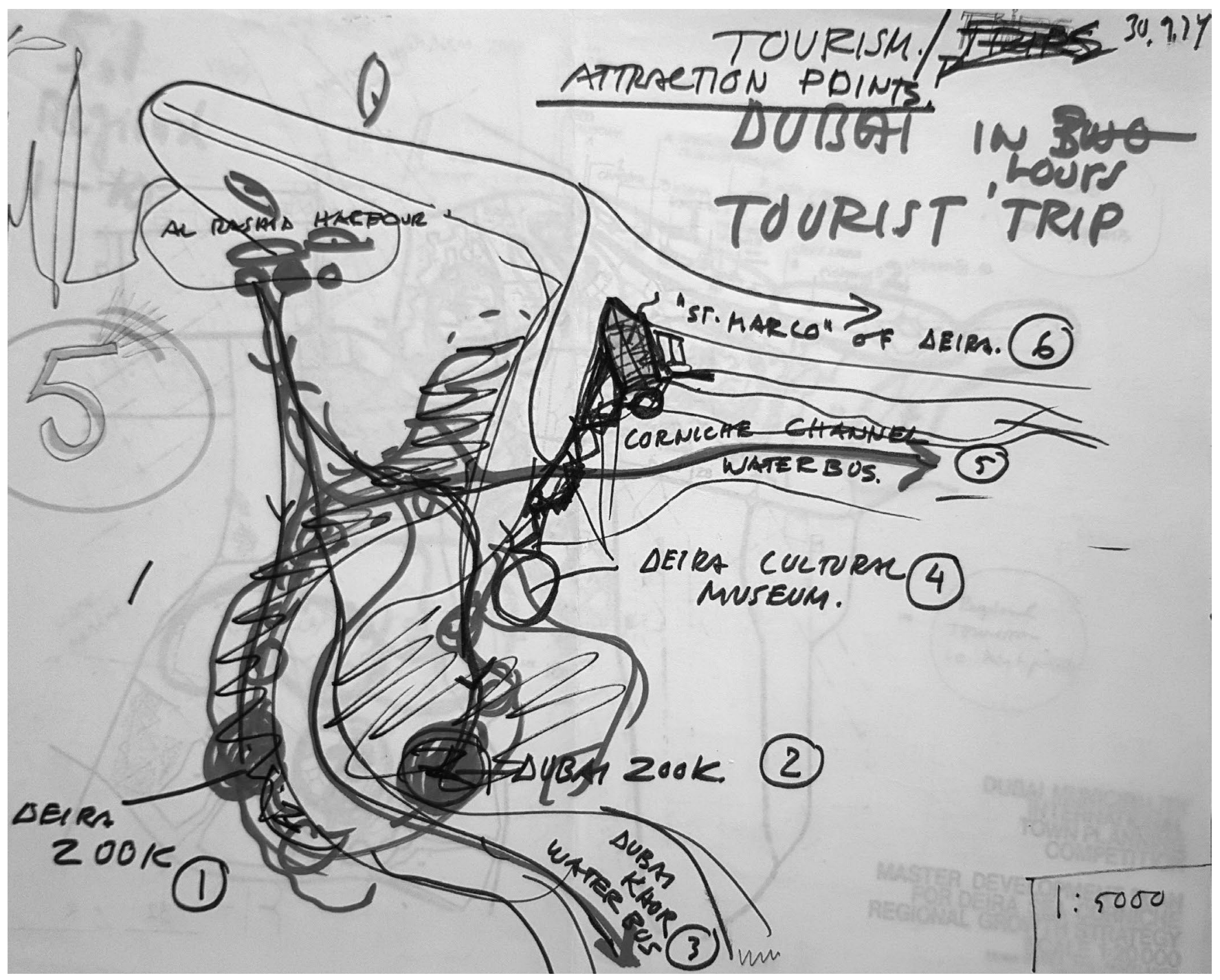

Figure 4: Sketch dated on “30.9.8.74" showing the reference to "St. Marco," 1974, Reima and Raili Pietilä's Archive, The Museum of Finnish Architecture. 


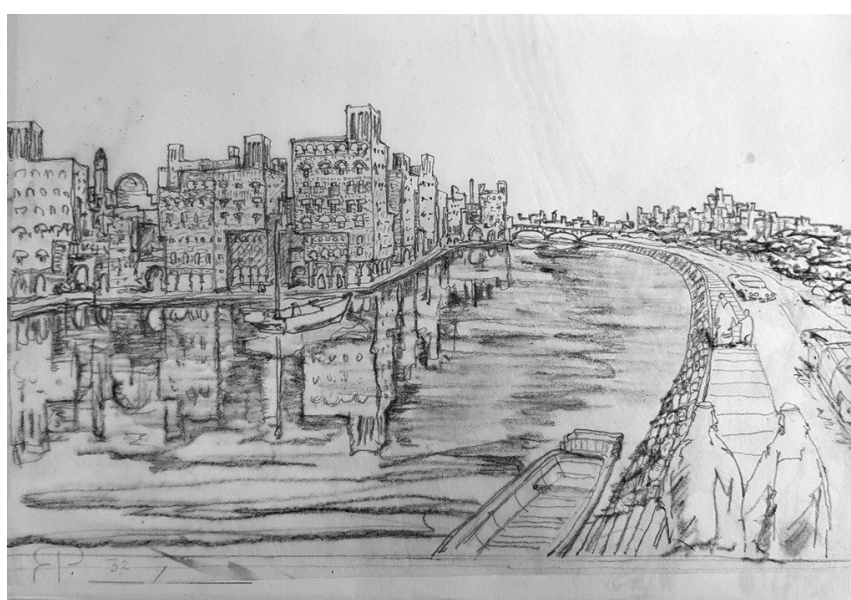

Figure 5: Sketch of the canal between the islands and Deira, 1974, Reima and Raili Pietilä's Archive, The Museum of Finnish Architecture.

In a following phase, the Pietiläs considered the possibility to create artificial bays along the coastline (sketches dated on "19.8.1974" and "22.8.1974"11), allowing the water entering the mainland as for the creek. The creation of this sequence of harbours, was a first attempt to extend the coast overall length, characterizing the areas and allocating the different functions.

A sketch dated on "30.9.1974"12 shows a sudden idea that will significantly affect the design, introducing a new main idea: in the corner between the outlet of the Creek and Deira, an architectural landmark marked as "St. Marco" is placed. It is a clear reference to the San Marco Basilica in Venice. Starting from this moment, the Italian town become a fundamental reference. Dubai was already called "the Venice of the Gulf"13 because of the Creek presence. The Pietiläs' proposal will enhance this analogy with the creation of a Cornice canal, inspired by Canal Grande in Venice. The canal was formed creating a sequence of artificial islands in front of the new coastline, connected to the mainland by means of bridges.

The reshaped coastline and the islands created an artificial lagoon, where the canal would have hosted several recreational and leisure activities connected by water taxis and water buses, as water was intended to become a mode of transport.

Each island had a mixed-use program, with taller residential buildings placed towards the canal side and the mainland, while open outdoor spaces and public facilities were faced the sea. Thereby, the group of buildings formed a C-shaped construction which left a public space as a core open to the sea.

The place of "St. Marco," in a strategic position between the Creek and the Corniche Canal, was taken by a leisure complex including a Sea Museum, Climatic Gardens and the Al Rashid Tower, the main architectural landmark of this core. Acting as the San Marco's Tower in Venice, and clearly visible both

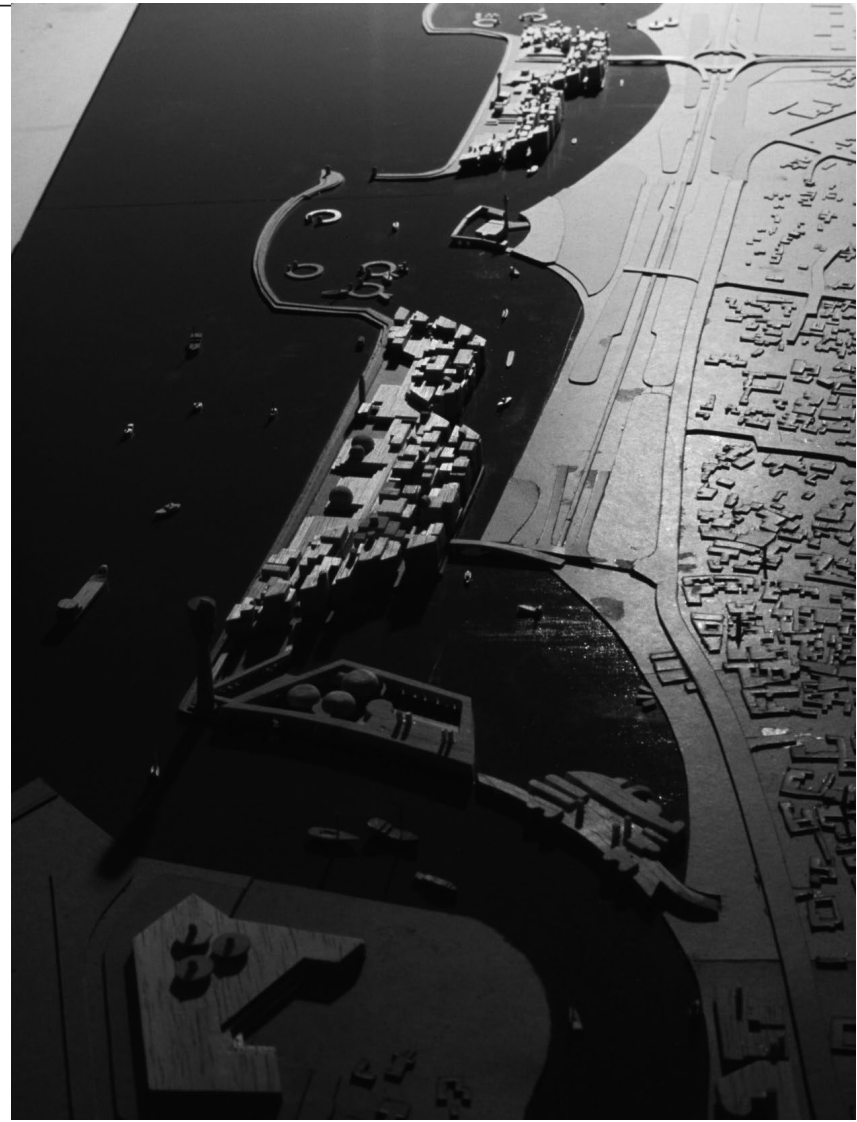

Figure 6: Image of the final model showing the relation of the islands with the Creek, 1974, Reima and Raili Pietilä's Archive, The Museum of Finnish Architecture.

sides of the Canal and the Creek, this building was intended to be an observatory tower with a revolving panoramic restaurant on top.

This new arrangement of the Corniche Canal was developed and presented as a final proposal, and its founding spirit is visible in a remarkable free hand perspective sketch by the Pietiläs.

In their research for the semantic identity of the city, the language of small scale architectural elements such as arcades and gates became landmarks of a living urban unity. Great attention was paid to the micro-climate of the city, looking at the sustainable solutions of the traditional Islamic city: nearness and sun orientation of buildings, built density creating shadow protecting public walks and pedestrian areas, small alleys oriented towards the sea in order to grasp the sea breeze and buildings with passive cooling and natural ventilation as in the local tradition of wind towers.

\section{CONCLUSION}

Architectural dLand reclamation has been a regular instrument of urban planning to produce new lands in coastal areas around the world. An ideal use would be focused on the extension of high density areas to avoid land misuse while 


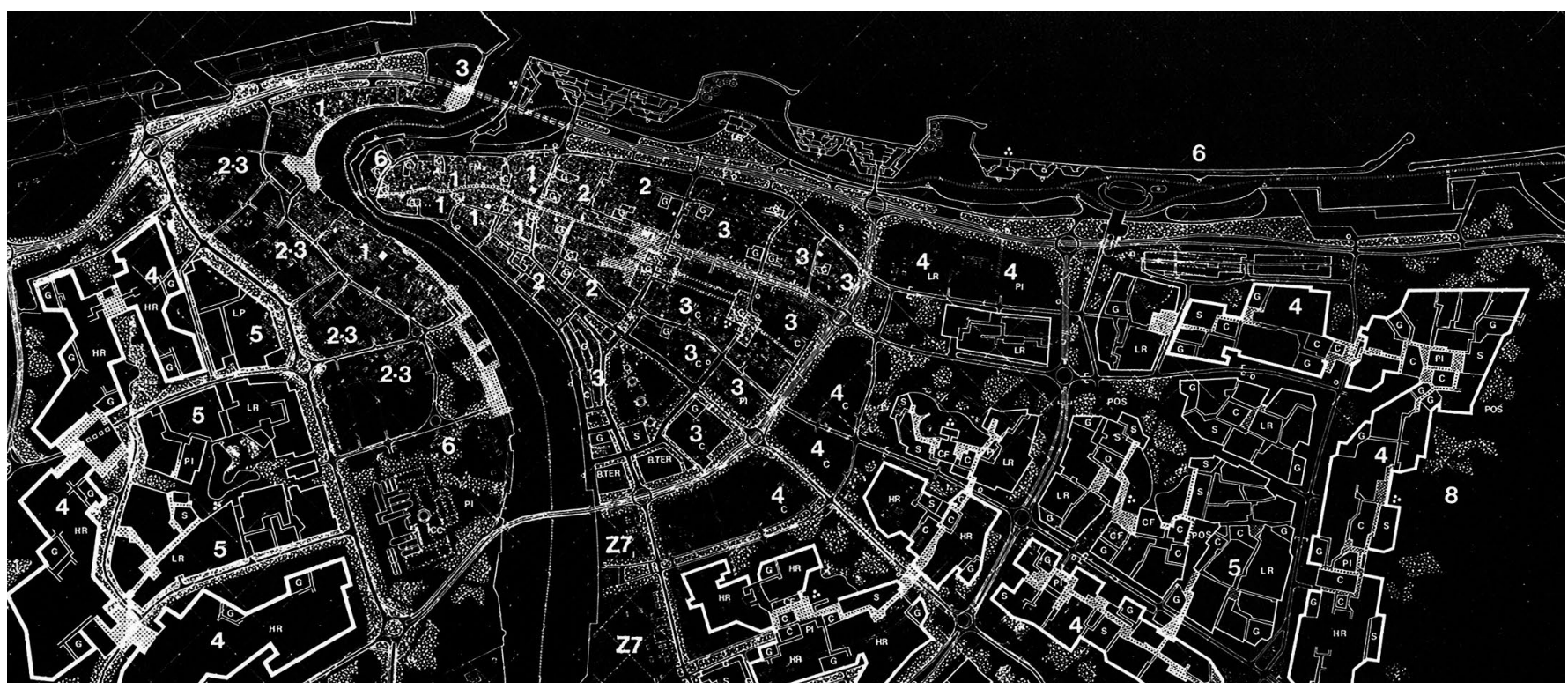

Figure 7: Final General Plan, 1974, Reima and Raili Pietilä's Archive, The Museum of Finnish Architecture.

allowing the preservation of most part of the coastline, and always guided by environmental impact studies. This is the reason why the current reality in Dubai cannot be highlighted, even if 70-80 per cent of the world's sea dredgers were working there before the 2008 financial crisis, as its interests are mainly focused on commercial values (dimensions, forms, styles...). Yet, it turns out to be pertinent to remember an old land reclamation proposed for Dubai several decades ago as this one tried to follow a strong urban impact analysis when this type of studies did not exist.

Pietiläs' land reclamation tried to re-establish the old values of the urban space, through "the cultivation of space" and "humanization of form." ${ }^{14}$ Because the current development determined by the technological revolution (importing western models), does not consider the primary human values and is destroying the cultural identity of the urban space in the traditional Arab cities. Therefore, the Pietiläs proposed a "culturalist approach"15 to attempt a respectful development of the tradition of the human values of the culture of the city to acquire more balanced urban growth strategy, and this approach must be remembered again as a main characteristic of this urban instrument.

\section{ENDNOTES}

1. Yasser Elshesthawy, Dubai: Behind an Urban Spectacle (London and New York: Routledge, 2010), 121.

2. Recently, Noel Murphy studied contemporary land reclamation in 8 cities around the world where Dubai was a case study with other cities with an older reclamation history as Venice or Rotterdam. Noel Murphy, (May 7, 2018), http:// www.noel-murphy.com/

3. "Nakheel to make major announcements at ATM," Staff Reporter, (April 23, 2006), Khaleej Times, https://www.khaleejtimes.com/article/20060423/ ARTICLE/304239981/1036

4. To know more about the growth of Dubai since the 50s see: Rubén García ( Present and the Future of Dubai," ZARCH Journal of interdisciplinary studies in Architecture and Urbanism, no. 8 (2017), 78-89; and Tiziano Aglieri Rinella, "Learning from Dubai: Behind an urban show" in Migration and the Built Serivizi Editoriali Integrati and DIARC Università degli Studi di Napoli Federico II, 2016), 207-215.

5. Some of the last coastal projects, especially the ones with a certain dimension are empty or not fully finished. Even thought, new coastal projects are being promoted and building during the writing of this text as the Dubai Harbour a "20 million square feet luxurious waterfront." "Dubai Harbour: Sheikh Mohammed unveils major new project with Middle East's biggest marina," Michael Fahy (January 2, 2017), The National, https://www.thenational.ae/business/ property/dubai-harbour-sheikh-mohammed-unveils-major-new-project-withmiddle-east-s-biggest-marina-1.40945

6. The Italian BBPR or George Canidilis were also invited. In reality, the commission awarded BBPR's proposal, which was much simpler and with a total differen approach than the Pietiläs' one. However, this winning plan was not followed up anymore. During the summer, the French government made some commercia agreements with the Government of Dubai, and the French diplomacy made some pressure the Ruler of Dubai to abandon the BBPR plan in favour of George Candils project, that was neither the most elaborated or the most flexible but was, at last, chosen. Neverthe of Dubai during the following decades.

7. Pietiläs' Archive preserves a document titled "International Town Planning Competition for the Preparation of: Master Development Plan for Deira-Sea Planner Saadallah N. Saadallah) on July 1974, with the requirements and information about the Competition. "International Town Planning Competition for the Preparation of: Master Development Plan for Deira-Sea Corniche," Deira Sea Corniche Competition, Reima and Raili Pietilä's Archive, The Museum of Finnish Architecture.

8. Ibid., Section 2: Terms of Reference, 3: Goals, p. 12

9. Ibid. Section 2: Terms of Reference, 6: Terms of References for the Consultants, p. 20.

10. There are still some images of this city on Pietiläs' file for this competition. Deira Sea Corniche Competition, Reima and Raili Pietilä's Archive, The Museum of Finnish Architecture.

11. Ibid

12. Ibid

13. The same Pietiläs used the expression on their remarks. "Dubai, publication material for Domus and A+U," 9: Water Potential, p. 4, Deira Sea Corniche Competition, Reima and Raili Pietilä's Archive, The Museum of Finnish Architecture.

14. Ibid., 5: Conclusions p. 5

15. Ibid. 